only, and is generally opposite the centre of the windings inducing the field under measurement. The ordinary procedure is to take the first reading at this point. The direction of this field, which may be considered as along the $x$-axis, is determined by turning the transverse exploring coil until a null reading is obtained, and the angular position of this null reading is determined from the dial. This represents the $y$-axis, and $90^{\circ}$ from this position is the $x$-axis. This determines the angular positions on the dial for the $x$-and $y$-axis, which will be used for all subsequent readings. The transverse exploring coil is then turned to be at right angles to the $x$-axis so as to obtain a reading of the maximum field. All other readings can then be given as a percentage of this maximum, which may ultimately be calibrated for actual field strength.

After the maximum field at the centre has been determined, the coil is moved along the $z$-axis in the same hole, and readings taken of all three components at short intervals. Where the field strength is changing rapidly, readings may be made at intervals as small as 0.05 in., distance being read on the graduated brass rod that carries the search tube. Farther out from the centre, where the field is weaker and is changing less rapidly, the distance between readings may be increased. Similar sets of readings can then be taken throughout the length of the remaining twenty holes.

\section{NEPHRIDIA AND GENITAL DUCTS}

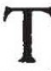

HE last two issues of the Quarterly Journal of Microscopical Science (86, Pts. II, III and IV) contain one memoir, and they will be received with mixed feelings of gratitude and sadness by zoologists throughout the world. Gratitude because they contain such an admirable review of the subject of nephridia and genital ducts, and sadness because the second part contains a notice of the death of their distinguished author, Prof. E. S. Goodrich. The reviewer suggests that, if the type is still available, the publishers of the journal consider the possibility of adding some personal notes and issuing the two parts together as a memorial volume. The publication of the second number almost coincides with Prof. Goodrich's twenty-five years as editor of this famous journal ; while his numerous publications in this field, in which he was an acknowledged master, extend over more than fifty years and, with one exception, have appeared in it-surely an exceptional record.

Accounts of the excretory organs and the genital ducts in a wide range of animals occurred frequently in previous literature, but they were difficult to correlate because of the lack of a generally accepted nomenclature, in part due to the fact that their true nature and origin were not properly understood. After original investigations of his own, Prof. Goodrich published in 1895 a memoir "On the Cœlom, Genital Ducts and Nephridia". In this for the first time the relationships of these structures were clarified, a much more satisfactory terminology was proposed and a series of important homologies pointed out. This work became a classic and formed a secure foundation for all future investigations on these topics.

In the fifty years that have passed since its appearance, a large volume of work along the same lines has been published, including noteworthy contribu. tions by Prof. Goodrich himself and others directly inspired by him. Naturally much has been added to our knowledge and new types of these structures discovered, and these are all referred to in their appropriate places in the present memoir. In spite of the elaboration of certain details, almost no modification of the fundamental ideas originally put forward has been found necessary. The present memoir bears the title "The Study of Nephridia and Genital Ducts since 1895" and is self-explanatory. It covers the whole range of triploblastic animals from the Platyhelmia up to and including the Vertebrata. It is illustrated by 100 text-figures and is furnished with a full bibliography. There is no doubt that, like its predecessor, it will furnish the standard work of reference for many years to come.

\section{FORTHCOMING EVENTS}

(Meetings marked with an asterisk * are open to the public)

\section{Tuesday, May 28}

EUGENICS SOCIETY (at the Royal Society, Burlington House, Piccadilly, London, W.1), at 4.45 p.m.-Discussion on "Eugenically Desirable Types" (to be opened by Mr. Geoffrey Eley, followed by Mrs. C. Bosanquet and Dr. Maurice Newfleld).*

LONDON ASSOCIATION OF UNIVERSITY WOMEN (at the Royal Institution, Albemarle Street, London, W.1), at 5.30 p.m.--Dr Kathleen Lonsdale, F.R.S.: "The History of the Royal Institution"

SOCIETY OF INSTRUMENT TECHNOLOGY (at the London School of Hygiene and Tropical Medicine, Keppel Street, London, W.C.1), at
6 p.m.-Dr. A. Porter: "The Design of Automatic and Manually Operated Control Systems".

\section{Wednesday, May 29}

ROYAL SOCIETY of ARTS (at John Adam Street, Adelphi, London, W.C.2), at 1.45 p.m.-Major W. H. Cadman: "Colloidal Carbon".

ROYAL STATISTICAL SOCIETY (at the London School of Hygiene and Tropical Medicine, Keppel Street, London, W.C.1) at 5.15 p.m.the British Empire, 1941-45".

\section{Thursday, May 30}

LONDON SCHOOL OF ECONOMIOS AND POLITICAL SCIENCE (at Houghton Street, Aldwych, London, w.C.2), at 4.45 p.m.-Prof. E. R. Hondelink: "The Organisation and Control of European Inland Transport".

Friday, May 31

Royal Astronomical Society (at Burlington House, Piccadilly, London, W 1), at $4.30 \mathrm{p}-\mathrm{G}$ sphere"' (to be opened by Sir Edward Appleton, G.B.E., F.B.S.).

\section{APPOINTMENTS VACANT}

APPLICATIONS are invited for the following appointments on or before the dates mentioned

LACTURER IN MATHEMATICS-The Clerk to the Governors, Mid Essex Technical College, Market Road, Chelmsford (June 1).

FNTOMOLOGIST for Colorado beetle, potato root eel-worm and genera d ithe Secretary, States' Committee of Agriculture, 6 Bond Street, St. Helier, Jersey (June 1).

Bond Street, S. CHEMISTRY up to B.Sc. standard-The Principal, Chelsea Polytechnic, Manresa Road, London, S.W.3 (June 6).

IN PHYSICS AND MathFi Venturers' Technical College, Bristol 1 (June 6).

(ungraded), and LEOTURER (ungraded), an ASSISTANT LECTURER (ungraded), and DEMONSTRATORS (3), IN THE DEPARTMENT OP

Registrar, The University, Liverpool (June . ASSISTANT LECTURER IN GROA

TECHNICAL DEVHLOPMENT SUPERVISOR for the organisation and TECHNICAL DEVHLOPMENT SUPER NISOR fOr the supervision of a Technical Development Section-The $\rightarrow$ Secreta

Development Board, 21 Fitzwilliam Square, Dublin (June 15). PROFESSOR AND HEAD OF THE DEPARTMENT OF

The Secretary, The University, St. Andrews (June 29). MrcologisT at the Tea Research Institute of Ceylon, Talawakelle, Ceylon-The Secretary, Ceylon Association in Londo

treet House, Arthur Street, London, E.C.4 (June 30). RESEARCH WORKERS to take part in an investigation of the distribution of drugs in cells using radioactive elements- Prof. Gaddum, Pharmacological Department, The University, Edinburgh (June 30), LECTURER IN MATHEMATICS $\triangle$ ND SUIENCE at the British Institute, Cairo-The Director of Education, British Council, 3 Hanover Street, London, W.1.

LECTURER IN MATHEMATICS, qualifled to teach to the standard of the Special Degree of London University-The Registrar, Municipal College, Portsmouth. 